International Journal of Child, Youth, and Family Studies (2014): 5(4.2) 751-781

\title{
THINKING WITH PAINT: TROUBLING SETTLER COLONIALISMS THROUGH EARLY CHILDHOOD ART PEDAGOGIES
}

\author{
Vanessa Clark, Veronica Pacini-Ketchabaw, and B. Denise Hodgins
}

\begin{abstract}
In this paper we think with the specificities of paint to tell stories about entanglements of settler colonialism and paint and painting in early childhood art education. We see to become implicated (Razack, 1998) within settler colonialism in the context we now call Canada. We paint a messy non-linear picture of our work with children through a process of storytelling. Through complex pictures of how we are attempting (even if partially and imperfectly) to respond and stay with the trouble our stories bring forward, we gesture toward hope and decolonizing strategies. Our work takes inspiration from contemporary artists and from anti-racist and Indigenous scholars.
\end{abstract}

Keywords: early childhood art pedagogy, settler colonialisms, paint, contemporary art, storytelling

Vanessa Clark is a Ph.D. student and sessional instructor in the School of Child and Youth Care at the University of Victoria, P.O. Box 1700, STN CSC, Victoria B.C., Canada, V8W 2 Y2. Email: vanessa.vondruska@gmail.com

Veronica Pacini-Ketchabaw, Ph.D. is a Professor in the School of Child and Youth Care at the University of Victoria, P.O. Box 1700, STN CSC, Victoria, British Columbia, Canada, V8W 2Y2. E-mail: vpacinik@uvic.ca

B. Denise Hodgins, Ph.D. is a sessional instructor in the School of Child and Youth Care at the University of Victoria, P.O. Box 1700, STN CSC, Victoria, British Columbia, Canada, V8W 2Y2. E-mail: dhodgins@uvic.ca 
International Journal of Child, Youth, and Family Studies (2014): 5(4.2) 751-781

A wrinkled drop cloth stained with paint is stretched across the floor of the child care centre. Long, white sheets of paper cover the surrounding walls. Red and yellow tempera paint is presented in bowls on the floor. Child and adult bodies move through the painting space. Amelia's small hands are filled with red paint as she moves around the enclosed painting space and then bends to stroke Edward's bare feet. Edward, in a diaper and an orange shirt, sits down as he looks at the red paint sticking and smoothing onto his feet and legs.

Paint stories are abundant in early childhood classrooms. Paint is present on walls, on children's bodies, in cupboards, on art shelves, and on easels. Paint is a primary item in the early childhood art supplies collection. It is mentioned in early childhood art curriculum books, articles, pamphlets, and posters. These resources describe the wide-ranging benefits of using paint in the classroom with young children: Paint helps children to explore mess and, importantly, to develop sensory awareness (Tarr, 1995); paint is a medium for self-expression (Duncum, 1982); children's painting actions and products help to convey their developmental progression (Kellogg, 1969; Lowenfeld \& Brittain, 1975); paint is a medium for thinking (Cavallini, Filippini, Vecchi, \& Trancossi, 2011; Ceppi \& Zini, 1998; Giudici \& Vecchi, 1994). The supply catalogues of early childhood education commonly market tempera paint as washable or non-washable as appropriate to the children's ages. Charts are included that offer a variety of colours, from deep robin red, to antique yellow, to royal blue, to titanium white. These stories of paint, mostly emphasizing children's growth and self-expression, are told over and over; they dominate discussions of early childhood art pedagogies. Yet, we argue in this paper, other paint stories can be told that might unhitch early childhood practices from individualistic and developmental accounts (see Burman, 2008) and entangle them in the worlds we inhabit with young children (Taylor, 2013).

In this article, then, we engage with the material-discursive presence of paint in early childhood art pedagogies by tracing stories of paint. We do this through a process of telling stories of paint and painting, such as the one presented above, and entangling classroom stories with other paint and painting stories that help to make paint more worldly (Haraway, 2008). Following Haraway (1997), we pull certain threads and knots to disentangle and reassemble stories that trace paint's emergence and geo-historical specificity. This process of telling, unpacking, untangling, and reassembling a wide range of stories allows us to paint a picture of our art pedagogy in the early childhood classroom.

The classroom stories we tell in this paper emerged from a three-year multisite collaborative inquiry and critical visual ethnographic project (Pacini-Ketchabaw, Kind, \& Kocher, 2012). The project's primary goal was to engage non-traditional approaches to materiality in early childhood classrooms through an investigation of art materials. Vanessa acted as an atelierista $^{1}$ during the project, and Veronica and Denise as pedagogistas ${ }^{2}$. The project

\footnotetext{
${ }^{1}$ As an atelierista, Vanessa attempts to bridge the practices of contemporary art, her own art, and early childhood education.

${ }^{2}$ As pedagogistas, Veronica and Denise work collaboratively with educators to deepen and broaden pedagogies in the classroom, including attending to ethical/political aspects of early childhood pedagogies.
} 
began as a way to address a concern that early childhood art processes, such as painting with a brush, for instance, are often seen merely as activities that contribute to children's social, physical, emotional, and creative development (Lowenfeld \& Brittain, 1975; Matthews, 2003). The majority of texts and curriculum documents emphasize what to do with such art materials, yet little is said about how one might think with and about these materials (Kind, 2010). Our goal was to investigate how art materials live in the world in multiple ways. For this paper we draw on observations of painting events in one classroom, using field notes, photography, and video recording. In addition to the stories we collected through our research, we include stories about painting that we found through our readings in art history and early childhood history, foregrounding the highly political nature of these stories.

Following post-qualitative approaches (Lenz Taguchi, 2012; MacLure, 2011), we write through a methodology we call thinking with paint to gesture toward a pedagogy that takes into account that paint participates in making the early childhood classroom and the classroom participates in making the paint. We employ paint's physicality to study its presence in the classroom and the world. Sullivan's (2006) description of painting, in part, inspires our methodology:

The term "painting” is both a noun and a verb. As a noun, there is ready acceptance that painting, as an object, has creative and material form, provenance, and a host of interpretive regimes through which it can be squeezed. However, when seen as a verb we get a sense of the way that painting as a practice is determined by the act of doing it. In this way, distinctions among terms such as painter, object, and viewer melt away as the circumstance or setting influences the meanings invoked in artistic efforts and encounters. (p. 30)

We therefore attend to the properties of paint - its viscosity, smoothness, slipperiness, stickiness, its ability to dry and solidify - as well as to what it does: how it spreads, how it covers, how it layers, how it mixes, how it transforms others and itself, leaving traces behind. Paint, we argue, drawing on Mol (2002), is multiple. We use its multiplicity as our "primary site and source of knowledge” (Sullivan, 2006, p. 31) to generate insights, problems, and disruptions in our early childhood practices.

Importantly, thinking with paint is a political act on our part; we aim to implicate ourselves and our early childhood education practices within the ongoing settler colonization of the lands in which we write this paper (Alfred \& Corntassel, 2005), which are now known collectively as Canada. Our research is conducted in unceded Coast and Straits Salish territories; specifically, we work in the territory of the Lekwungen (Esquimalt and Songhees Nations). Through European colonialism and imperialism, these lands were violently stolen from Indigenous peoples. While colonialism has shifted and moved, and continues to shift and move (Alfred \& Corntassel, 2005), Eurocentric motives of the colonial project remain powerful, and colonialism still exerts an explicitly violent power that seeks to empty lands for settler occupation and profit (Byrd, 2011; Morgensen, 2011; Tuck \& Yang, 2012). Like Andrea Smith (2011), we understand colonialism to structure all of society. As but one example, the education system (Battiste, 2004), including early childhood art education, is a site in which we all learn to participate in the logic of colonialism. 
By situating and implicating ourselves in destructive (albeit active and creative), violent, imperial colonialist practices, we attempt, through our art pedagogy, to respond to the amnesia of settler colonialism (Hilden \& Lee, 2010). In engaging colonialism in this way, we hope that our work can contribute to decolonizing efforts. Yet, we are leery of calling our work decolonizing, as Tuck and Yang (2012) remind us of the problems in doing so. For example, as we show in this paper, even though we attempt to respond to settler colonialism, we cannot stand outside its messy, implicated, ongoing activities, and thus we recognize that there is no easy binary of colonizing/decolonizing. Also, Victor (2006) reminds us that "the hows, whys and whens of decolonization must come directly from ... Indigenous peoples themselves” (p. 2). Our art pedagogy is therefore a motion toward becoming implicated in settler colonialism, as we work to continually think through its complexities, creativities, and shifting and changing activities (Alfred \& Corntassel, 2005). We hope this paper outlines some of these messy implications and shows how we have just begun to partially and imperfectly respond to the ongoing colonization of Indigenous peoples and their lands. We understand that this beginning gesture is not enough, and it does not absolve us from our implication. It is simply a gesture.

In this paper's first section, we describe thinking with paint as a political act in colonial spaces. Our approach draws on the important work of Indigenous and anti-racist feminist scholars (Arvin, Tuck, \& Morrill, 2013; Hilden \& Lee, 2010; Razack, 1998) in that it questions settler colonialism and takes an anti-essentialist perspective ${ }^{3}$. Razack (1998) proposes that a fruitful approach "is to ascertain how, at specific sites, patriarchy, white supremacy, and capitalism interlock to structure [identities] differently and unequally” (p. 159). In this paper we are interested in tracing threads of unequal and differentiated relations that emerged through paint. We draw inspiration from four contemporary artists: Rick Rivet, Rebecca Belmore, Bently Spang, and Vanessa Dion Fletcher. In the second section, we work with paint's viscosity, smoothness, and slipperiness, and we play with these qualities to tell and trace 16 colonial stories of paint. The stories we tell, if ever partial, allow us to inquire into paint's, and our own, implication with colonial past-presents as we engage in our pedagogical work in the classroom. In section three, we continue to implicate paint, painting, and our early childhood practices in colonialism by exploring what paint does. Finally, in our conclusion, we come back to our intentions with this paper, and our hope that the stories we tell in this paper will reverberate through early childhood education.

\section{Thinking with Paint in Colonial Spaces}

We come to this work through various white and racialized settler positions. Colonialism always plays with racialization, and, while the two are different, they interlock and nourish one another (Razack, 1998) to support white settler empire building (Byrd, 2011). These positions, which we acknowledge locate us differently, simultaneously benefit the state through our continued acknowledgment of ourselves as being in white and minoritized positions. So, in this paper, we attend to how we are organized and organizing ourselves into these positions through

\footnotetext{
${ }^{3}$ Although we take an anti-essentialist view in this paper, we do not want to discredit important essentialist movements - especially those that bring forth "identity" - as these have been done strategically. We also realize that not all movements based on identity are essentialist. As Simpson (2011) describes, for example, in Nishnaabeg, sovereignty is something more than an essentialist strategy.
} 
white hegemonic humanist representations (Hall \& Jhally, 2009) and how these roles "may sustain [settler colonialism] and its naturalization” (Morgensen, 2011, p. 22) ${ }^{4}$.

When we start to trace paint, immediately we notice problems with this ubiquitous art material. We question, for instance, the presence of paint in early childhood as an innocent practice that sits outside of all the violent doings of colonialism. Following Razack's proposal, we trace paint-educators-children-ourselves-early-childhood-practices as implicated in differentiated and unequal relations - and therefore as accountable to shifting these relations that continue to produce us unequally. We ask, for example, how might paint's geographies and histories transform childhood, educators, practices, us? What might happen when paint's geographies and histories enter early childhood art spaces?

Drawing on Arvin et al.'s (2013) call to feminist literature to attend to the workings of settler colonialism, we centre a critical engagement with settler colonial relations, and we do that through telling stories. In responding to the work of Indigenous women and Native feminists, we tell and listen to stories of violence and survival through our thinking with paint. Arvin and colleagues (2013) insist that listening and responding means more than just hearing: It means being deeply changed in ways yet unknown. So, without knowing what this collection of stories will do, we tell stories that flow smoothly, stories that are slippery, stories that stick, and stories that have solidified practices. Following our thinking with paint methodology, we aim to proliferate stories that have become invisible, stories that mask unequal relations, stories that are layered, stories that become intertwined, and stories that transform paint forever. We do not, of course, present these stories to tell the truth about paint and painting and their implication in colonial pasts-presents. Instead, we tell stories to interrupt, to reformulate, and to build new stories. As we noted in the introduction, following Haraway's work, our stories are a way of pulling threads and loosening knots in early childhood education art practices; in turn, we entangle other stories with the hope of producing different relations.

Yet, we tell stories with caution. Razack (1998) puts forward important questions about the ethics of storytelling. She asks: "To what uses will these stories be put? Will someone else take them and theorise from them? Will they serve to reassure [taken-for-granted ideas]? Who will control how they are used?” (p. 37). We also wonder what stories have not been told. For instance, European art stories are readily available and easy to find; they have dominated art history. But stories grounded in Indigenous ontologies and epistemologies have been silenced in art history texts; therefore, they have not made it into this paper. Although the ethical struggles these questions bring have no easy answers, we keep them here, and in a sense they haunt us through our writing.

Thinking with paint through Indigenous and anti-racist feminisms allows us to engage with the long colonial history that is often silenced in much of contemporary art history (Becker, 1996; McEvilley, 1998; Shiner, 2003). Much of the art we know today emerged from material and discursive practices of colonial relations (McEvilley, 1998). For instance, art has been

\footnotetext{
${ }^{4}$ Although we attempt to complexify our acknowledged white and racialized positions, and take an anti-essentialist view in this paper, we also understand that no amount of complexity should erase the "meaningful difference indigeneity continues to make in a settler society, as in Native sovereignty struggles and national and transnational Native alliances” (Morgensen, 2011, p. 22).
} 
International Journal of Child, Youth, and Family Studies (2014): 5(4.2) 751-781

classified in relation to who invented it and who gets to claim ownership over it. Contemporary aesthetics are considered high art, while Indigenous aesthetics are understood to be cultural and are placed within the realm of anthropology. Indigenous artists making art today using Indigenous aesthetics are categorized as traditional, and their art is often referred to with the racist name of primitivism (McFadden, n.d.). Shiner (2003) writes:

Scholars and critics ascribe [the invention of art] to the ancient Chinese and Egyptians, and once the European colonial grip was firmly established, Western artists and critics discovered that the conquered people of Africa, the Americas, and the Pacific had all along possessed something called "primitive art." (p. 3)

Between the 1870s and 1930s, museum collectors around the world rushed out to preserve art from the northwest coast of North America because they assumed these communities were dying cultures (McLennan \& Duffek, 2000). We wonder how these histories are present in early childhood practices, how they act as silenced stories of colonialism. We wonder, too, what our obligations and responsibilities are to inherit these stories - without paralyzing our practices and whether, in inheriting them, we can still provide hope for early childhood.

To think through these inquiries, we turn to the works of contemporary artists: Rick Rivet, Bently Spang, Rebecca Belmore, and Vanessa Dion Fletcher. First, our thinking with paint approach takes inspiration from Rivet's blurring of binaries of colonizer/colonized and good/bad (Smith, 2012), which are often resurrected in texts attempting to challenge art (e.g., Becker, 1996; McEvilley, 1998; Shiner, 2003). Rivet (n.d.), who works ${ }^{5}$ to subvert Eurocentric histories of art, says:

My contemporary art approach is ... derived from Western and International art traditions, past and present. These traditions were influenced to a great extent by shamanic-based art of great sophistication (e.g., art forms from North/South America, Oceania and Africa). Artists from the Western and International art scenes took a great deal from these sources; as for instance the work of Gauguin, Van Gogh, Joseph Beuys, Picasso, Paul Klee, the Abstract and German Expressionists, et cetera. These artists incorporated the art forms, thereby creating a prism through which they could discover themselves.

My role as an artist is not to represent "Indigenous", "Native”, or "First Nations" art, as the current labelling or pigeonholing goes. My work is, in this Post Modernist time, tending toward a more comprehensive portrayal of my interests as an artist. I feel that my themes and the character of the work reflect a more universal interest which cannot be constricted within the narrow confines of terms such as "Western", "Native", "Hybrid", "Canadian" or what have you. My art represents aspects of my own culture and history personally, and in the wider archetypal sense, includes all common human experience. (para. 13-14)

\footnotetext{
${ }^{5}$ Rick Rivet's artwork can be viewed at the following web link: http://www.rickrivet.ca/
} 
A second inspiration is A Way of Making (Belmore \& Spang, 2003), an exhibit curated by Reona Brass (Cree/Saulteaux, Saskatchewan, Canada) that features the work of Northern Cheyenne artist, Bently Spang and Anishnabe artist, Rebecca Belmore ${ }^{6}$. Spang and Belmore looked at "how ritual in performance art functions in fashioning a new self within the cultural body. Taking up residence in a studio at Ontario College of Art and Design the artists [explored] the boundary between what we understand as 'authentic experience' and what is 'merely performed' to discover how this practice functions in creating a cycle of cultural desire, resistance and fertility” (Belmore \& Spang, 2003, para. 2). This exhibit helps us think about boundaries - the importance of making boundaries, the destruction of boundaries, and the dangers of both -between "authentic" and "performance”.

Finally, Vanessa Dion Fletcher's piece “Body Prints” inspires us to pay attention to the materiality of bodies, paint, and communication. Dion Fletcher's work (see Figure 1 below) asks us to respond, albeit imperfectly, to colonialism, and to think about new ways of communication within the tensions in which we find ourselves through colonialism.

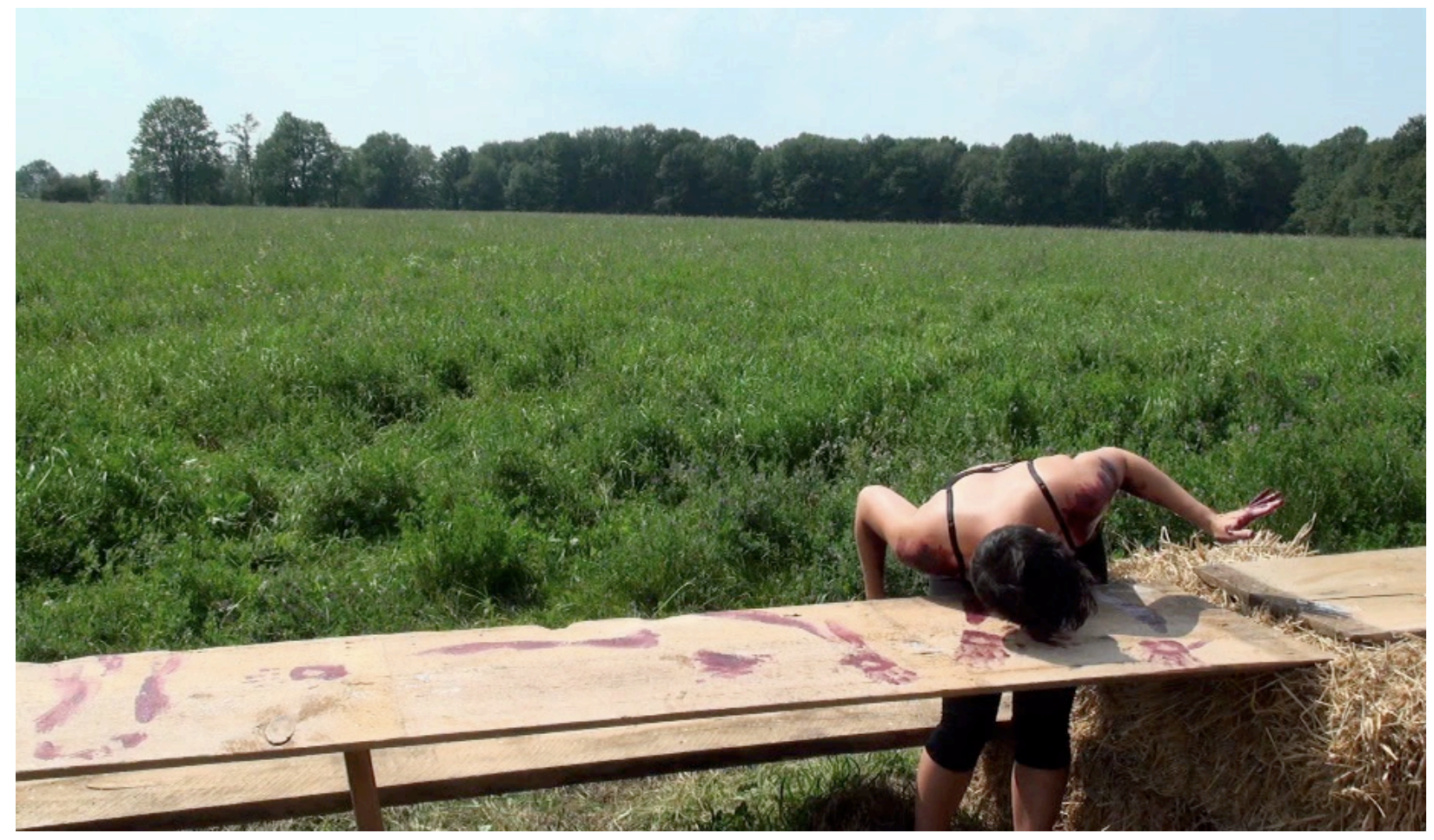

Figure 1. Fletcher, painting table with body (with the permission of the artist).

\footnotetext{
${ }^{6}$ A Way of Making by Rebecca Belmore and Bently Spang can be viewed at the following web link: http://ccca.concordia.ca/performance_artists/b/belmore/belm_perf1/index.html
} 
International Journal of Child, Youth, and Family Studies (2014): 5(4.2) 751-781

Fletcher (n.d.) writes:

My art practice is a process of investigating the influence of culture and politics on the relationship between our bodies and the land. I create art using composite media, primarily working in video, print media and performance. The different physical forms of my work provide a diverse theoretical language to draw on.

I focus on ideas of fluency and understanding in the context of my Potawatomi and Lenape ancestry. My interests in communication come from my lack of access to my indigenous languages (Potawatomi and Lenape) and as a person living with a learning disability caused by issues with short-term memory. Having no direct access to my ancestral Aboriginal languages has inspired me to explore the notion of communication without words. Through my artwork I am undertaking a process of recording or archiving in a way that is outside of the inescapable colonialism associated with only being able to speak English. My performance and two-dimensional works exist in a tension between action and output, where the definition[s] of art vs. documentation are blurred. (n.d., para. 2-3)

Collectively, these contemporary artists speak of violence and hope, and importantly, they stay with the tensions that imperialism and colonialism bring without seeking smooth solutions. Their art is situated in the midst of these tensions. We draw inspiration from their art, both collectively and individually, to tell stories from our art practice in early childhood. We, too, attempt to work in the midst of the tensions that colonialism brings, while also attending to hope. We engage with hope cautiously, however, as we do not claim to present any easy escapes from colonialism's grasp. Next, we turn to performing thinking with paint.

\section{Attending to the Properties of Paint: Viscous, Smooth, and Slippery Stories}

In this section we show how paint emerges side by side with - and thus contributes to shaping - colonial efforts of empire. To foreground and to implicate ourselves and our practices in the workings of colonialism, we trace paint's dubious properties. We say dubious because it is extremely difficult to pinpoint paint's properties, since paint differs depending on the surface to which it is applied, the temperature when it is applied, and the length of time it is exposed to air. Paint is further complicated because its properties largely depend on the desired effect.

Paint can be viscous, smooth, slippery, or sticky. Viscosity, a complex concept, describes the ease with which paint flows. The more viscous (thicker) the paint, the more force it takes to make it flow (Valluzzi, 2011). Viscosity functions as the result of force on the sediment structure of units of areas within the paint. In other words, viscosity is an internal friction of the paint moving when force is applied to it (Avramov, 2005).

Paints may be based on water or oil, and many substances can be added to them to make them like one another. Additives can change paint in other ways, too. For example, if clay is added to watercolour paint, it becomes very viscous, but less sticky than oil paint. An acrylic paint is extremely versatile; it can take on the properties of a fluid watercolour or a highly viscous oil paint. Artists might strain their paints to take out any lumps or grit, so that the paint is 
International Journal of Child, Youth, and Family Studies (2014): 5(4.2) 751-781

perfectly smooth on the canvas. For example, an artist might strain a viscous oil paint, and a smooth application would signal the artist's skill. Oil paint can be quite rough and hold the brush strokes on the canvas. In certain circumstances, rough brush strokes are desirable to show, for example, movement.

Properties such as smoothness, stickiness, and slipperiness are related to, but different from, viscosity. Generally speaking, the more viscous a paint, the more it sticks to surfaces. Watercolour paint, for example, is not very sticky; it is runny and needs to be soaked into the paper. Oil paint is usually highly viscous and sticky. However, when paint thinner is added to oil paint, it becomes fluid and loses its stickiness. Encaustic paint, using heated wax as a binder, is generally fluid when heated, but also sticky. Encaustic paint can be sculpted when it is dry, making it even more interesting.

Slipperiness, also related to viscosity, makes paint even more complex. Oil paint, which is highly viscous, is generally not very slippery, and will take more effort to glide onto a canvas. Watercolour paint, which is thin, is not very slippery on paper and will soak right in unless the paper is already saturated. However, watercolour on hands or feet, as we discovered while painting with the children, is very slippery. Tempera paint, which is less viscous than oil paint but more so than watercolour, is also very slippery.

As we noted in the introduction and have highlighted in this brief description of paint's properties, paint (like colonialism) is multiple (Mol, 2002) and therefore never one thing. Paint (like colonialism) constantly shifts depending on what is added to it, what it rubs with, where it goes, what day or time of day it is used, how it is applied, and so on. The 15 stories that follow, when read through this complex picture of paint, rub against each other, touch, slide, and find unexpected partners, creating entanglements that don't necessarily tell truths; rather, they form messy connections in a mixed-up world (Haraway, 2008).

\section{Story 1: Body painting}

The walls and floor of a classroom are covered in stained white drop cloths. Long panels of Plexiglas in brown wooden frames stand in the centre of the room. Black bowls of white and purple tempera paint sit on the floor with a number of paintbrushes strewn around. Sheila pushes her small hands and then the back of her forearms into the purple paint. She leans over and applies white paint to the bottom and top of her right foot. Then she lifts her foot up to the Plexiglas and paints it using the bottom and top of her foot. Bending down to the floor, Sheila places one arm in the white paint and one in the purple. When she stands up, she can see the viscous white paint slowly drip down her forearm toward the floor. She holds her hand out to catch the drip before it separates off and then she smears it onto the Plexiglas. Sheila clenches both hands and watches closely as the thick white paint squishes and seeps slowly out of her fists in long tendrils. Tempera paint's viscidity invites Sheila into the mess of paint. The paint sticks to Sheila. It is thick, and under force it flows. The paint is also smooth and slippery, so that when Sheila clenches her hands around it, the paint escapes her grasp. Tempera paint is slippery and difficult to hold. 
International Journal of Child, Youth, and Family Studies (2014): 5(4.2) 751-781

Paint's force to escape, in the story above, makes us wonder about histories of tempera paints like the one that escapes from Sheila. The word tempera comes from the Italian tempare, which Fuga (2006) explains means "to dissolve or mix in the right dosage" (p. 112). Tempera paint is made up of pigments, binders, and additives (Valluzzi, 2011). The way it is created has changed and morphed throughout time and space based on the ingredients that constitute it. For example, casein tempera paint is made with a binding agent derived from skim milk. Vegetable gum temperas are made with the sap from acacia trees or astragalus shrubs (Kirsh \& Levenson, 2000). Yet, these stories of casein and vegetable gum tempera paint are scarce in the literature. Much more has been written about tempera paints made using chicken eggs as a binder and mixed with pigments from ground plants and minerals (Drogin \& Zucker, n.d.). Chicken egg tempera paint has appeared in many historical accounts of paint, as well as in paintings, as we discuss below.

\section{Story 2: Chicken egg tempera paint}

In the Byzantine Empire, chicken egg tempera was used in religious icon paintings.... Traditional egg tempera paint is still used by the Orthodox Church today (Arnold, 2004). Traces of tempera paint proliferate through icon paintings like "Christ Pantocrator" (see Figure 2 below). This medium reached its peak in the Middle Ages, "up to and well into the $15^{\text {th }}$ century" (Fuga, 2006, p. 112). Traces of tempera paint can be seen in Egyptian, Greek, and early Renaissance art in Europe (Arnold, 2004). In the early $16^{\text {th }}$ century, Leonardo da Vinci painted The Last Supper in tempera (Fuga, 2006). Egg tempera was the primary medium of Western easel painting through the early Renaissance (Kirsh \& Levenson, 2000).

The majority of the art history texts we came across in our literature review (Arnold, 2004; Fuga, 2006; Kirsh \& Levenson, 2000; Kissick, 1993) tell these kinds of stories of paint as matters of fact. We are interested in what stories like this one, presented as fact, do to bodies. We think that facts have effects, facts act, and so we turn to the work of anti-racist and Indigenous feminists to help us unpack what these stories presented as facts might do to bodies. Sheila, whom you met in Story 1, also helps us to pay attention to bodies. When we look at Figure 2, and Story 2, we see only certain bodies at work: holy white Christian bodies. Ahmed (2007) explains that colonialism functions by making certain bodies more at home than others. Similarly, stories and paintings work to place certain bodies at home while making others feel out of place. These bodies slip easily into our uses and conceptualizations of paint in the classroom. 
International Journal of Child, Youth, and Family Studies (2014): 5(4.2) 751-781

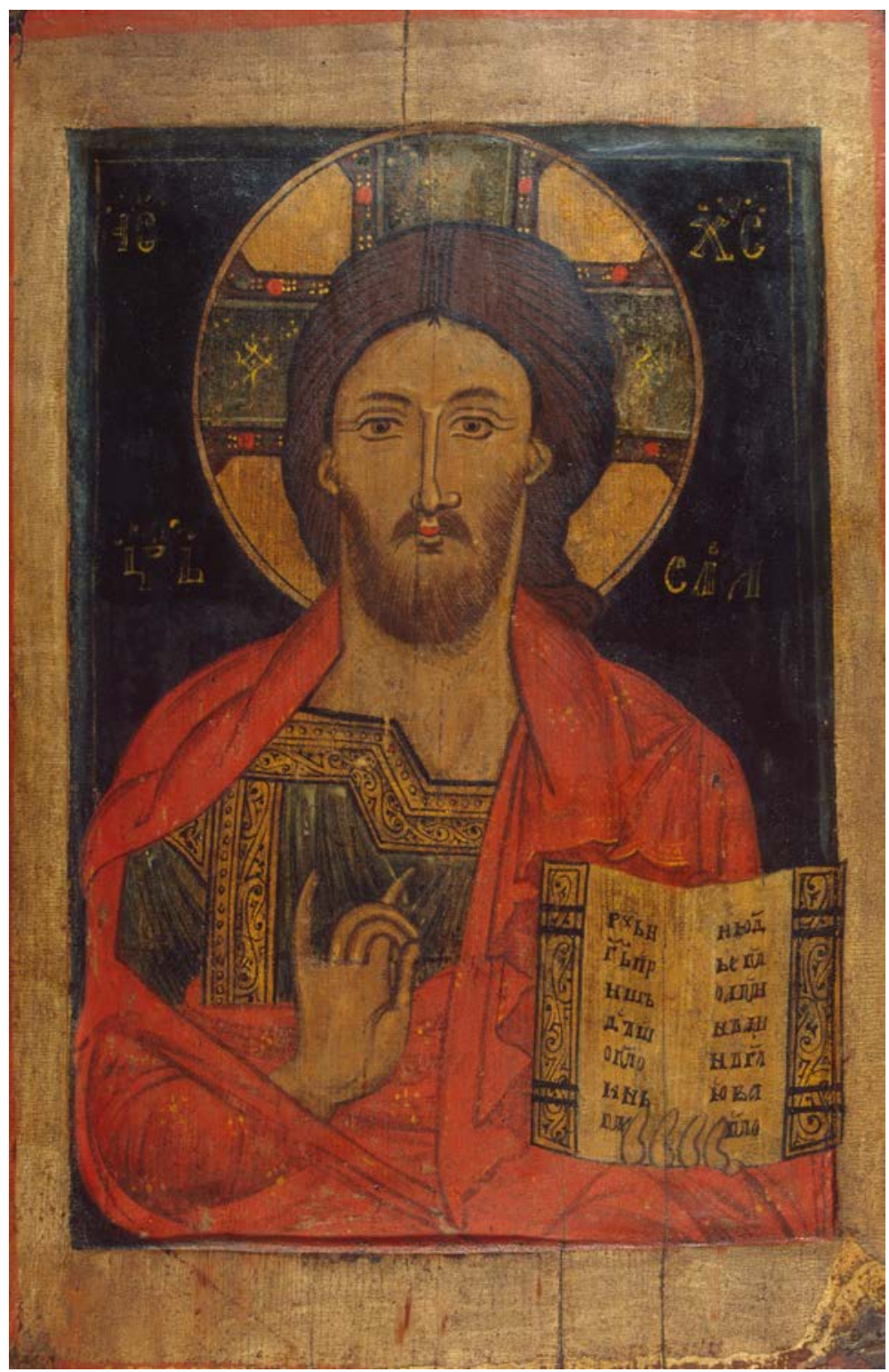

Figure 2. "Christ Pantocrator," Christ holding book (with the permission of The State Hermitage Museum, St. Petersburg, Russia).

Looking through paint's viscosity, getting into the thick tempera paint, we notice that our stories become grittier. When we study Renaissance art, McEvilley (1998) writes,

we rarely think that in fact slave raiding and early colonialism was the background on which that art was taking place and that social function which that art was serving had something to do with this background - the fact, for example, that in 1509, about the time Leonardo painted The Last Supper and Michelangelo began work on the Sistine Chapel, the first shipload of enslaved Africans arrived in the Caribbean, and then in 1619, again a kind of crucial moment in the history of art, African slaves began to be sold at auction in Richmond, Virginia, and so on. (p. 19) 
International Journal of Child, Youth, and Family Studies (2014): 5(4.2) 751-781

We see how art - painting in this case - has a social function and is implicated in early colonialisms. The gritty story of paintings' entanglement with colonialism, told by McEvilley (1998), helps us to reflect on the smooth paint stories of early childhood education art practice. What might it do to bring gritty stories to the classroom? How would Sheila's body, for example, respond to grit? How would moist, gritty dirt respond to Sheila's body? What kinds of classroom dialogues and conversations would be inspired? Paint can be messy in the classroom, but it might also become gritty and thick if we attend to histories of colonialism.

\section{Story 3: Gritty political work}

Wanting to see what might emerge when we paint with grit, we offered children a space to work, large sheets of canvas, and moist dirt. In the process of collecting moist, thick dirt, we scooped up twigs, shredded leaves, little rocks, and bits of roots. We wanted to retain all the bits and pieces instead of attempting to sift the dirt. Painting with dirt becomes forceful, strenuous. Bodies move differently and are marked differently. Yet, dirt washes faster than tempera paint. It even appears, in some strange way, as though our bodies absorb the dirt. The canvas is also marked, and we notice that over time these marks fade as the gritty elements of dirt fall from the hanging canvas.

We asked ourselves, how might we respect the dirt? And importantly, how do we know when something has been done respectfully? We also wondered what knowledges we embody through our engagements with dirt, and how we connect to dirt differently than we connect to tempera paint. We explored in this work with dirt how we might know, embody, and think with dirt differently than we do with tempera paint. What might these two materials set in motion in relation to painting? This is our political work in the classroom. 


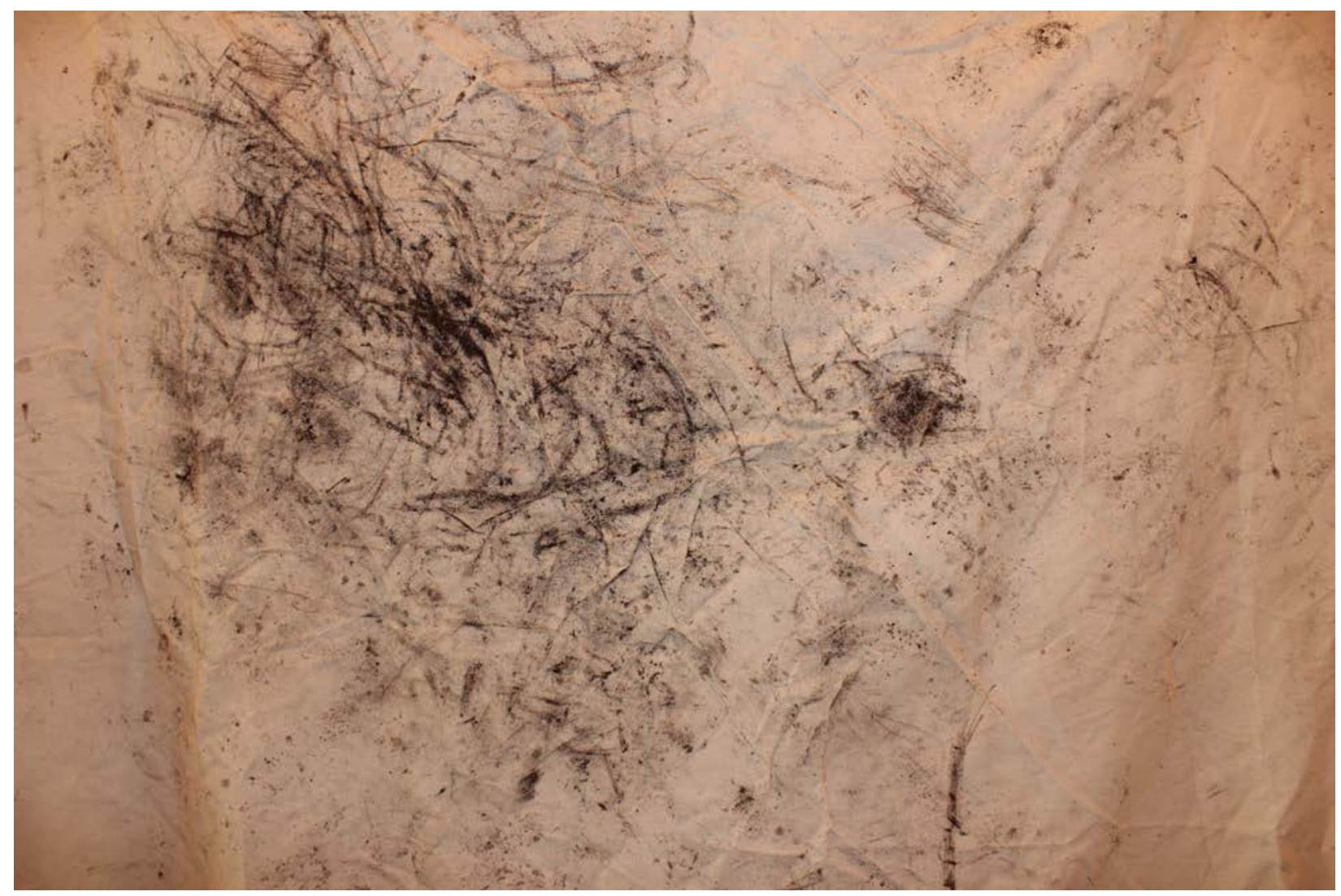

Figure 3. Dirt on canvas (photo by Vanessa Clark).

Our next stories move us further into paint's viscosity. Each type of paint has a different thickness, or viscosity. Oil paint is thicker than tempera paint, for example, and our oil paint stories become thicker, too.

\section{Story 4: Painting "the Indian," painting "the wild" - Ways of seeing}

In 1585, Roark (2003) writes, "the artist John White accompanied the first expedition of English settlers to Virginia, at the eastern coast of North America" ( $p$. 1). Irish settler Paul Kane followed and documented Indigenous people in Canada through drawings later materialized to oil paintings; Kane sought to document a dying "race" (McFadden, n.d.). Many of the 19th-century North American landscape paintings emerged when artists were commissioned to bring back representations of the "unknown" world to Europeans during colonial excursions to the Americas (Smith, 2012; Steele, n.d.). For example, German artist Albert Bierstadt, a member of the Hudson River School, painted the American West (Landscape Oil Painting Gallery, n.d.). In Canada, Emily Carr produced many oil paintings of diverse Indigenous communities in and around what we now know as Vancouver Island in British Columbia. Like Paul Kane, Carr was known for documenting a "dying culture" (Braun, 2002).

Sticky stories like the one above describe how paint participates in producing what Braun (2002) calls "ways of seeing". Seeing here refers to seeing "the Indian" and "the wild". Ways of 
International Journal of Child, Youth, and Family Studies (2014): 5(4.2) 751-781

seeing materialize through paintings and stories, like those we have been describing, but also, as Braun describes, through books, maps, photographs, and drawings. These materializations shape people and places. Ways of seeing also matter, as people and places are shaped according to certain logics. These logics are historical, political, ethical: They produce asymmetrical relationships to which we are accountable.

As ways of seeing, the paintings we have looked at function through the logic of settler colonialism. Andrea Smith (2011) exposes this logic, which depends on the erasure of Indigenous peoples from the land in order for the colonial state to exist and profit:

As many Native scholars have argued, Native peoples are entrapped in a logic of genocidal appropriation. This logic holds that Indigenous people must disappear. In fact, they must always be disappearing, in order to allow non-Indigenous people's rightful claim over this land. Through the logic of genocide, non-Native people then become the rightful inheritors of all that was Indigenous - land, resources, Indigenous spirituality, or culture. (p. 50, italics in original)

We can see that paintings and stories of the dying Native, of disappearing Native culture and the unknown wilderness, support the logic of genocide.

Note that our stories have morphed, from smooth and slippery to sticky and viscous. Yet, by attending to the properties of paint and stories about paint, we do not mean to suggest that smooth and slippery is better than sticky and gritty, or that either is more innocent than the other. Just as paint is messy (in that we cannot pinpoint one clear definition of paint), so is settler colonialism, and it functions through sticky, viscous, smooth, and slippery stories.

\section{Story 5: Colonialism through rhythm, tangents, and poetry}

Next, we tell another story in relation to artist Emily Carr, this time an excerpt from her diary. To us, Carr speaks, among other things, of the romanticism and benevolence of painting the other. Note how colonialism smoothly enters the story.

Slept till nearly noon. Went with Miss Buell and Mrs. Housser to tea at Mr. A. Y. Jackson's Studio Building. I loved his things, particularly some snow things of Quebec and three canvases up Skeena River. I felt a little as if beaten at my own game. His Indian pictures have something mine lack - rhythm, poetry. Mine are so downright. But perhaps his haven't quite the love in them of the people and the country that mine have. How could they? He is not a Westerner and I took no liberties. I worked for history and cold fact. Next time I paint Indians I'm going off on a tangent tear. There is something bigger than fact: the underlying spirit, all it stands for, the mood, the vastness, the wilderness, the Western breath of go-to-the-devil-if-you-don't-like-it, the eternal big spaceness of it. Oh the West! I'm of it and love it. (Diary of Emily Carr, November 14, 1966, p. 24)

Over her lifetime, Carr created countless oil paintings of Northwest Coast communities and peoples ${ }^{7}$. Although she engages the presence of "the Indian" as she tells in the story above, she

\footnotetext{
${ }^{7}$ Emily Carr's work can be viewed at the following web link: http://www.emilycarr.ca/
} 
International Journal of Child, Youth, and Family Studies (2014): 5(4.2) 751-781

benevolently portrays the "noble savage" amid "pure space". She romanticizes the other when she describes her love of "the Indians" as the West - a vast, wild, empty space. It is important to consider, as Braun (2002) suggests, how Carr's paintings tell the public how to see Indigenous communities and landscapes in particular ways. We are reminded by the smooth, loving story above that the logic of colonialism enters articulation and writing in sneaky ways. Carr is a "Canadian icon" and her paintings of the northwest coast are part of the Canadian imagination of "history". In other words, her paintings are part of the constitutive elements of Canada (Braun, 2002).

We conclude this section with another story from our classroom research-pedagogy. Here, instead of leaving these gritty, smooth, slippery, thick stories of colonization outside the classroom, we invited them in - not as innocent stories, but as stories that disrupted us all, created tensions, pushed and pulled us in many directions. Here, paint is both smooth and gritty.

\section{Story 6: Children painting with Yuxweluptun}

We set up the projector in the classroom with images of Coast Salish artist Yuxweluptun's paintings "Usufruct" and "Scorched Earth: Clear-Cut Logging on Native Sovereign Lands, Shaman Coming to Fix.” The lights in the room are off, and the colours from the paintings project onto a wavy, white-tiled wall at the back of an open space. Child bodies move through the colourful images. A few children take up brushes and paint onto the tiled wall, with Yuxweluptun's painting "Usufruct" in the background. The children's painting mingles with Yuxweluptun's projected painting. The art piece marks the children's bodies as they paint.

In the classroom, we work in the middle of smooth, gritty, viscous, sticky stories of colonization, and we struggle to respond to them. Attending to artwork, such as Yuxweluptun's paintings above, for instance, we are aware of tensions about appropriating the paintings, about omitting pieces like this from our practices, and about inviting these paintings into the classroom in respectful ways. We are also aware of the bodies that are present and those that are absent. We struggle to imperfectly presence the diverse, vibrant Indigenous ontologies and epistemologies while staying with colonialism's viscous, smooth, and gritty tensions. We question ourselves while working with Yuxweluptun's paintings, not as a cultural or cross-cultural recognition, but as regeneration: What is this art piece doing? What can we know and not know? Might this way of seeing tell us of both violence and hope? Alfred (2010) says about Indigenous artwork:

Art becomes meaningful when it is part of a process of a human being/artist striving to excavate ancient and suppressed memories and working with them to regenerate and reinscribe our presences on the landscape. Notice I didn't say cultural presence. That's because I am not talking about striving for mere cultural recognition or working to facilitate understanding across cultural boundaries. I am talking about the land and other creatures and the spiritual forces that make up our world, what all of these have to teach us about being human, and once again taking up our responsibility within this confederacy of beings. (para. 5) 
International Journal of Child, Youth, and Family Studies (2014): 5(4.2) 751-781

We attempt to relate to Yuxweluptun's paintings so that they may teach us about ways of seeing, about regeneration, about what we might be able to know and the limitations of our knowing.

\section{Attending to What Paint Does}

In this section, we tell more stories, to continue to implicate paint, painting, and our practices in colonial processes. While in the previous section we used the properties of paint to tell stories, in this section we play with what paint does. Through stories of layering, covering, changing, and spreading, we show the knotty relations through which paint, and our pedagogies, are always already entangled and implicated in settler colonialism—even as we work to untangle some of these relations.

\section{Layering and covering}

\section{Story 7: Covering layers of paint with more paint}

Stephan stands in front of a large sheet of Plexiglas marked with long, dried, blue streaks of paint. Thick red tempera paint saturates the bristles of the paintbrush he holds. Standing up tall on his toes, he brushes quickly up and down with the red paint. He moves around the side of the Plexiglas to the bowl of red tempera and saturates his brush again. He picks up the bowl and brings it with him, then brushes on more red. The red paint layers onto the dried blue paint underneath.

We are interested in what the paint does in Story 7, specifically, how it layers. The blue paint is dry, so it doesn't mix with the red. Instead, the red paint covers up the blue paint beneath. How the paint layers and covers gives us important concepts with which to tell stories. Our next story is therefore told in three layers as a way to make one - the first - a bit more blurry.

\section{Story 8: Layering and blurring}

The first layer of our story is about particular ingredients used in a specific painting.

Italian artist Alberto Sozio's painting "Crucifix" was finished in 1187. The painting was created through many layers. The base of Christ's body was achieved through mixing chicken egg yolk with lead white and other earth tones. Black was achieved using charcoal (Fuga, 2006).

The second layer of our story also speaks to the particular ingredients in paint.

Indigenous artists from the Northwest Coast used fish eggs as binding agents for pigments. George Hunt (1921, as cited in Boas, 1921) tells the following story about a Kwakiutl artist from the Northwest Coast.

He takes spawn of the dog-salmon, chews it, and spits it into his paint-dish. He takes coal and rubs it in the place where is the salmon-spawn that has been spit out. When it is really black, he takes his paint-brush, dips the end of the paint- 
International Journal of Child, Youth, and Family Studies (2014): 5(4.2) 751-781

brush into the black color, and paints all around the rim of the dish in this way. When this is done, he puts it away so that it dries. Then it is done. (p. 58)

The third layer of our story speaks of the blurring that takes place when ingredients in paint are layered.

Miller, Moffatt, and Sirois (1990), on behalf of the Canadian Conservation Institute (CCI), analyzed 1,346 paint samples "taken from a selection of ethnographic artifacts ... used by the Haida, Kwakwaka'wakw, and Tsimshian, among other groups. ... Through such techniques as infrared spectroscopy, $x$-ray diffraction, scanning electron microscopy, and polarized light microscopy, the CCI identified native pigments used prior to contact with Europeans and traced the introduction and impact of trade pigments" (McLennan \& Duffek, 2000, p. 90). Contact with Europeans changed the pigments and binders Indigenous peoples used for paints, and colours imported from elsewhere became available. For example, Shearar (1969) states that "early in the nineteenth century, fur traders began to offer powdered vermillion from China that produced a bright red" (p. 81).

These layers speak to us of the difficulty of searching for origins in our art pedagogies. Once again, we find the work of Indigenous feminists instructive. "Native” and "non-Native," Andrea Smith (2011) says, are regulated identities that act to position bodies in power relations to one another, as degrees of citizenship within empire. "Within this colonial imaginary," she continues, "the Native is an empty signifier that provides the occasion for Europe to remake its corrupt civilization" (p. 48). These identity locations "inform all power in settler societies and their relations with societies worldwide” (Morgensen, 2011, p. 1). Altamirano-Jiménez (2008) states:

First Nations, Métis, Inuit, Mixed Blood, Mestizos, Indians, and other labels are a reflection of the complex racial distinctions that today characterize North America and Indigenous peoples' relations to the national series. In fact, one of the most diverse issues affecting Indigenous Peoples in this region involves who has a legitimate right to define his or her identity and by what criteria, and by whose definition this assertion may or may not be true. (p. 178)

Tracing an origin for tempera paint is tricky because paint stories are layered in the racial and colonial distinctions that inform the power relations in settler societies through which the paint becomes. Through layering, we begin to unhitch paint from Euro-Western origins and complicate those origins by bringing other stories into the classroom. We question the certainty of Euro-Western origins and make it porous; that process brings transformation. When these stories are layered, we might see how paint takes us beyond this binary into messy, complex entanglements. We play with the dangerous actions of layering and covering to blur the pure and untouched Renaissance story of tempera paint - and tempera paint as emerging from the Eurocentric imagination - and simultaneously work to disrupt the story of the damaged paint of the colonized. These layers frame the paint differently and move us into asking how and why the paint becomes (Instone, 2009).

The layered story also moves us into conversations about paint that avoid the 
International Journal of Child, Youth, and Family Studies (2014): 5(4.2) 751-781

settler/colonizer binary of what paint is and allow us to see the complexities and tensions in which paint and our painting pedagogies are situated. We can then question whose interests are served when paint is conceptualized as belonging to colonizer or colonized. These layers take inspiration from Rick Rivet's artwork that attempts to blur the binary of colonizer/colonized.

To layer Story 8 even further, our next story speaks of artwriting, that is, about the politics of writing the stories we have been telling. Artwriting is an important aspect of how art is understood. It matters, for instance, whether artworks are displayed in coffee table books, museum brochures, critical articles, popular magazines, history texts, and so forth. The artwork communicates as well as becomes something different in each of these mediums, each implicated in settler colonial relations (Berman, 2012). Artwriting “directs the reader or consumer to see works of art in specific ways” (McChesney, 2012, p. 5).

\section{Story 9: Artwriting}

"Listening to Our Ancestors: The Art of Native Life Along the North Pacific Coast" by Robert Joseph (2005) was published by the Smithsonian Museum in collaboration with the National Geographic Society and the National Museum of the American Indian (both U.S. organizations). It includes commentary by First Nations speakers from various regions of the northwest coast discussing their own artwork. The book offers perspectives from various Nations (the Coast Salish, Makah, Nuu-chah-nulth, Kwakwaka'wakw, Heiltsuk, Nuxalk, Tsimshian, Nisga'a, Gitxsan, Haida, and Tlingit Nations) on the collection of their cultural treasures (carvings, weaving, etc.) by the National Museum of American Indians. Kwakwaka'wakw Chief Robert Joseph contrasts the way in which anthropologists and art historians view Native culture with the way Indigenous Peoples from the northwest coast see their culture.

Northwest coast art, when it is written about, is usually chronicled by museums, by European anthropologists or ethnographers, or as some form of collaboration (perhaps even coercion) with Indigenous Peoples (see Eaton \& Urbanek, 1995; Joseph, 2005; McLennan \& Duffek, 2000; Miller et al., 1990; Smyly \& Smyly, 1973; Turner, 1992; Wyatt, 1999). So, stories of art are never innocent and are entangled in the forces of Western categorizations (Smith, 2012), placing northwest coast art, as cultural, within museums, and contemporary art as high art (McFadden, n.d.). The chicken-egg paint stories we tell come from books categorized as high art, while the fish-egg story we tell above is from an anthropology book.

The stories we have been telling of tempera paint made from chicken and fish eggs can be layered further by telling of complex relationships between paint and corporations. Multinational companies suggest new relationships with land, animals, and people (Byrd, 2011), as well as with paint. Chicken egg paint, for instance, relates to multinational corporations through practices such as farming, domestication of chickens, management of animals, and so on. The use or nonuse of fish eggs in paint also alters relationships to fish and to land. With the story we tell next, we add another layer to the stories above. 
International Journal of Child, Youth, and Family Studies (2014): 5(4.2) 751-781

\section{Story 10: Capitalism meets paint}

The paint manufacturer Winsor \& Newton emerged in London in the early 19th century. By the middle of the 20th century, chemical companies manufactured paint, and paint became primarily synthetic (Temkin, 2008). Chicken and fish eggs are no longer used as binding agents for tempera paint.

The tempera paint that is used today in childcare centres across what we call North America is sold in a variety of brands. One common brand, Crayola, is manufactured by the multinational company Crayola LLC. The American government was one of Crayola's first customers; it used their products in their Indian residential schools (Armstrong Hall, 2006). Crayola now makes about 1.5 million bottles of paint every year (DeVan, 2008).

Various other brands of tempera paint are offered in addition to Crayola. A popular children's art supply store in Port Moody, B.C., for example, offers the brand Funstuff, which is marketed as a Canadian brand option for those who want to "stay local" and support the Canadian economy. However, Funstuff Liquid Tempera Paint is a product of Reeves and Poole Group Inc, (n.d.) which is based out of Toronto and outsources manufacturing to Thailand, South Korea, Taiwan, and China.

Thobani (2007) tells how the creation of "Canadian identity" situates settlers as Native while simultaneously erasing Indigenous Peoples. Paint that is marketed as a Canadian brand acts in similar ways to create a "Native paint". Thus paint is entangled in the making of Canadian identity. Further, since the "Canadian" brand is manufactured in Asia, our appetite for paint is fed through outsourcing to offshore companies.

In our art pedagogy with children in the classroom, thinking with concepts such as layering and covering allows us to engage in the fibre of deeply political practices. In Story 7 , Stephan takes up red tempera paint and plays with layering and covering the blue. In similar ways, when we decide to keep an easel with dry paint in the classroom for children to engage in layering and covering, we are attempting to play in our work with the depth of layers we spoke about through Stories 7 and 8, to engage the histories with our stories and our bodies as we work. As artist Vanessa Dion Fletcher paints a farm kitchen table with her body (working with ways to communicate beyond English), we are reminded that there are multiple ways to layer - layering that speaks to remembering, as well as layering that speaks to creating anew. We conceptualize paint and painting in our art pedagogies as layering and covering, yet it is also important to remember that there is always another layer.

Next, moving with the spread of paint, we tell another story about colours and the spread of a specific art pedagogy through the Waldorf schools created by Rudolf Steiner. This story takes place in the early 20th century, when colonial practices were spreading to Indigenous lands in what is now known as North America, forever changing the lives and lands and histories of Indigenous Peoples and the world. 
International Journal of Child, Youth, and Family Studies (2014): 5(4.2) 751-781

\section{Spreading and Changing}

\section{Story 11: Steiner and paint}

Rudolph Steiner was a philosopher, scientist, educator, and Goethe scholar who, in the early 20th century, founded a philosophical movement called anthroposophy (from Greek, meaning human wisdom). Steiner shared his views about art, spirituality, and education during one of 14 lectures that he gave to the teachers of the Independent Waldorf School at its founding in 1919:

The secret is that Goethe always imbues each separate colour with a feelingshade. He emphasizes, for instance, the rousing quality of red, he emphasizes not only what the eye sees, but what the soul experiences in red. In the same way he lays stress upon the tranquillity, the self-absorption, experienced by the soul in blue. It is possible, without jarring on the child's naivety, to introduce him into the world of colour so that the feeling-shades of the world of colour issue forth in living experiences. (If, incidentally, the child gets itself at first thoroughly grubby it will be a good step in his education if he is trained to get himself less grubby.) Begin as early as possible to bring the child in touch with colours, and in so doing it is a good idea to apply different colours to a coloured background from those you apply to a white surface; and try to awaken such experiences in the child as can only arise from a spiritual scientific understanding of the world of colour. (Steiner, 1937, para. 4-5)

Built by Emil Molt, owner of the Waldorf-Astoria cigarette factory in Stuttgart, Germany, the Waldorf School originally served the children of the factory's workers and management. Steiner was the school's director until his death in 1925, and in those six years, Waldorf evolved into a demonstration school for a radical new form of education. Today, there are 870 Steiner/Waldorf schools globally in 60 countries (Ashley, 2009, p. 210). At a 1922 lecture, Steiner told the audience:

It is immensely important that children should come to a right experience of colour. If you use the little blocks of colour of the ordinary paint box and let the child dip his brush in them and on the palette and so paint, he will learn nothing. It is necessary that children should learn to live with colour, they must not paint from a palette or block, but from a jar or mug with liquid colour in it, colour dissolved in water. Then a child will come to feel how one colour goes with another, he will feel the inner harmony of colours, he will experience them inwardly. And even if this is difficult and inconvenient - sometimes after the painting lesson the class-room does not look its best, some children are clumsy, others not amenable in the matter of tidiness - even if this way does give more trouble, yet enormous progress can be made when children get a direct relation to colour in this way, and learn to paint from the living nature of colour itself, not by trying to copy something in a naturalistic way. (para. 32)

We notice that the Waldorf School was created in collaboration with a cigarette company trying to profit from specific relations to the land through agricultural practices. We notice, too, how the pedagogy spread throughout Europe and North America, with 870 Waldorf Schools, and how this pedagogy created specific relations to paint and its colours (how they are understood, 
International Journal of Child, Youth, and Family Studies (2014): 5(4.2) 751-781

how they are presented to children, and how children should learn them) through models of best practices. The way stories such as Steiner's spread makes us wonder about the spreading of Euro-Western ideas throughout the world.

Battiste (2004) eloquently reminds us that Eurocentric knowledge is a form of imperialism in education:

Knowledge invented elsewhere and imported to the educational schools is often and rightly understood to be a weapon of cognitive imperialism (Battiste, 1986) wielded by educators who have it against those who must suffer it, a form of conquest and occupation of minds (Nandy, 1983) that serves to further colonize the life worlds of First Nations peoples (Duran \& Duran, 1995), and to marginalize Indigenous humanities and voices. (p. 13)

So, we question our art pedagogies in the classroom. Where did our understandings of what art is about, how art should be presented to the children, and what the children should be learning come from? What understandings are embedded in our art pedagogies? What is our responsibility to disrupt and respond to imperialism?

Rudolf Steiner had a specific understanding of the life world of colours, for example, the tranquility of blue. We wonder how the spread of an innocent understanding of colours might sit alongside our next story about blue. We follow the spread of religious stories through egg tempera paint as we focus on Leonardo da Vinci's "Madonna and Child” (see Figure 4). 
International Journal of Child, Youth, and Family Studies (2014): 5(4.2) 751-781

\section{Story 12: Ultramarine blue}

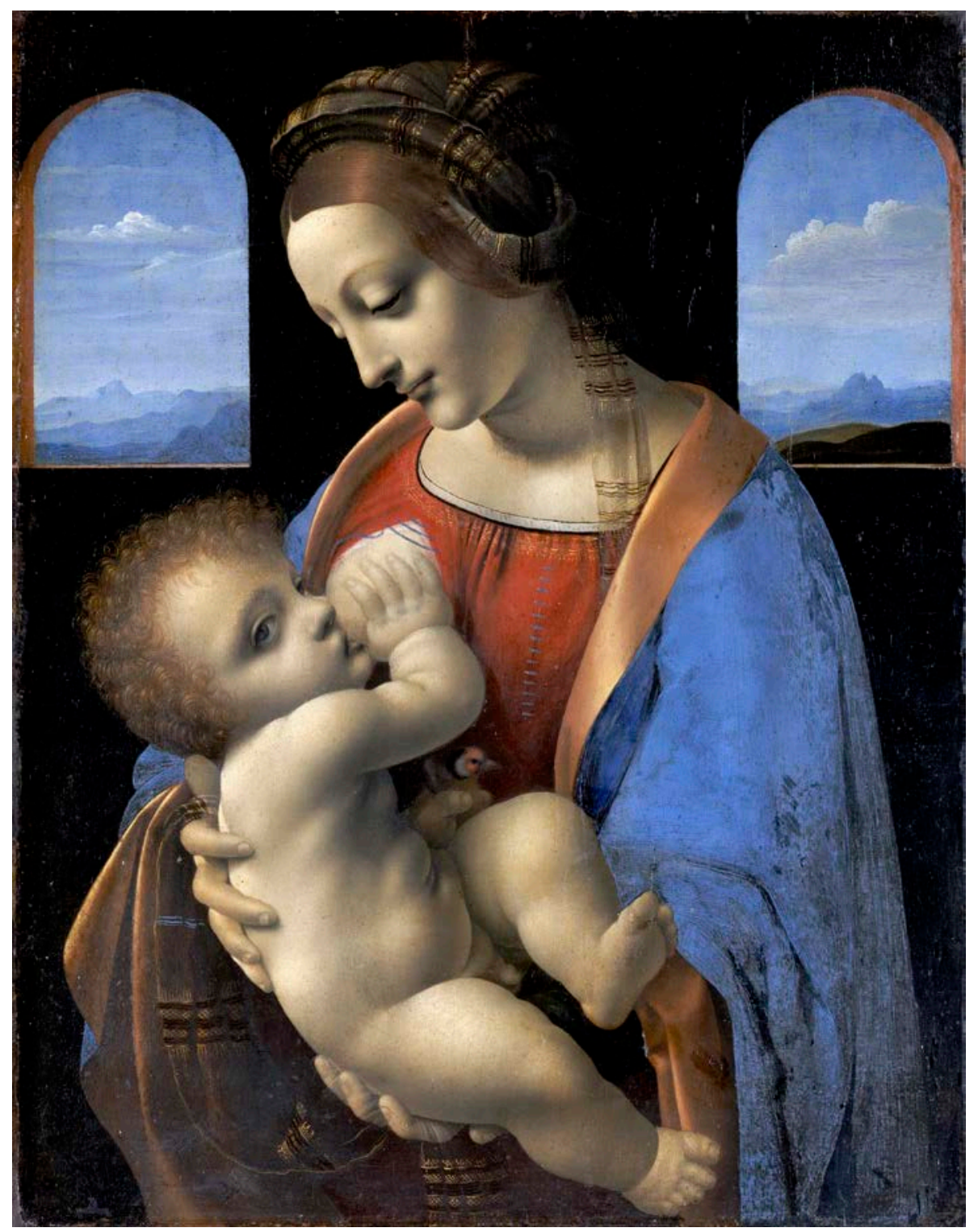

Figure 4. Leonardo da Vinci's Madonna and Child (with the permission of The State Hermitage Museum, St. Petersburg, Russia).

During the period of Renaissance art, tempera paint storied many religious images of the virginity of the white mother of "our" saviour. Paint made from the ultramarine blue mineral lapis lazuli was the most expensive and was imported to Italy from what we now know as Afghanistan. Blue was therefore the most valued colour, and it was reserved for special tasks, such as becoming the white virgin's gown (Drogin \& Zucker, n.d.). In the 19th century, a synthetic version of ultramarine blue was created (Fuga, 2006).

We think about how specific colours of paint perform specific tasks in stories. Paint travels, is imported, and takes on social meaning through its scarcity. Paint, in all its particularities, is 
International Journal of Child, Youth, and Family Studies (2014): 5(4.2) 751-781

important. These particularities emerge in their relating to bodies and they also participate in shaping bodies. Virginity and whiteness are produced - through the particularities of ultramarine blue. We follow the spread of colours through another story, this time to the science of colour.

\section{Story 13: Colouring the wheel}

European chemists, writers, artists, and politicians such as Newton, Goethe, Chevreul, and Harris attempted, through the colour wheel (see Figure 5, below), to universalize colour. These men built off of each other's works to develop the colour theory we use today (Bleicher, 2012). During 19th century colonial developments, "there was a shift that gave the various hues more romantic sounding names such as canary yellow and Tahitian green" (Bleicher, 2012, p. 21). Industrial growth in the 1950s brought other changes to colour names, with introductions such as "bubble gum pink" and "fire engine red". Bleicher (2012) writes that colours "were being named by manufacturers to boost the sales of their product. During the 1960s and 1970s, the names of colors became synonymous with commercialism and consumerism. . . Color names are developed by an industry to fit their particular need" (p. 21). In 1999, the Crayola crayon colour "Indian red" became "chestnut" to "erase any perceived connection with American Indians" (Armstrong Hall, 2006, p. 180).

Beginning in the 1880s, colour charts became available as business marketing encouraged the public to paint their own houses themselves. Pantone, an international colour-matching system, suggests how colour has become globally standardized. In another effort to standardize colour internationally, the Commission International D'Eclairage, or CIE, was formed in 1931 and introduced a standardized colour table (Bleicher, 2012, p. 31). The CIE used the primary colours red, green, and blue (RGB) to match colours mathematically instead of by eye. The International Color Consortium (ICC) and the Inter-Society Color Council (ISCC) were similar efforts to the CIE (Bleicher, 2012). Computer technology took up the RGB colour theory, as well as numerous other theories, as part of digital colour theory. 


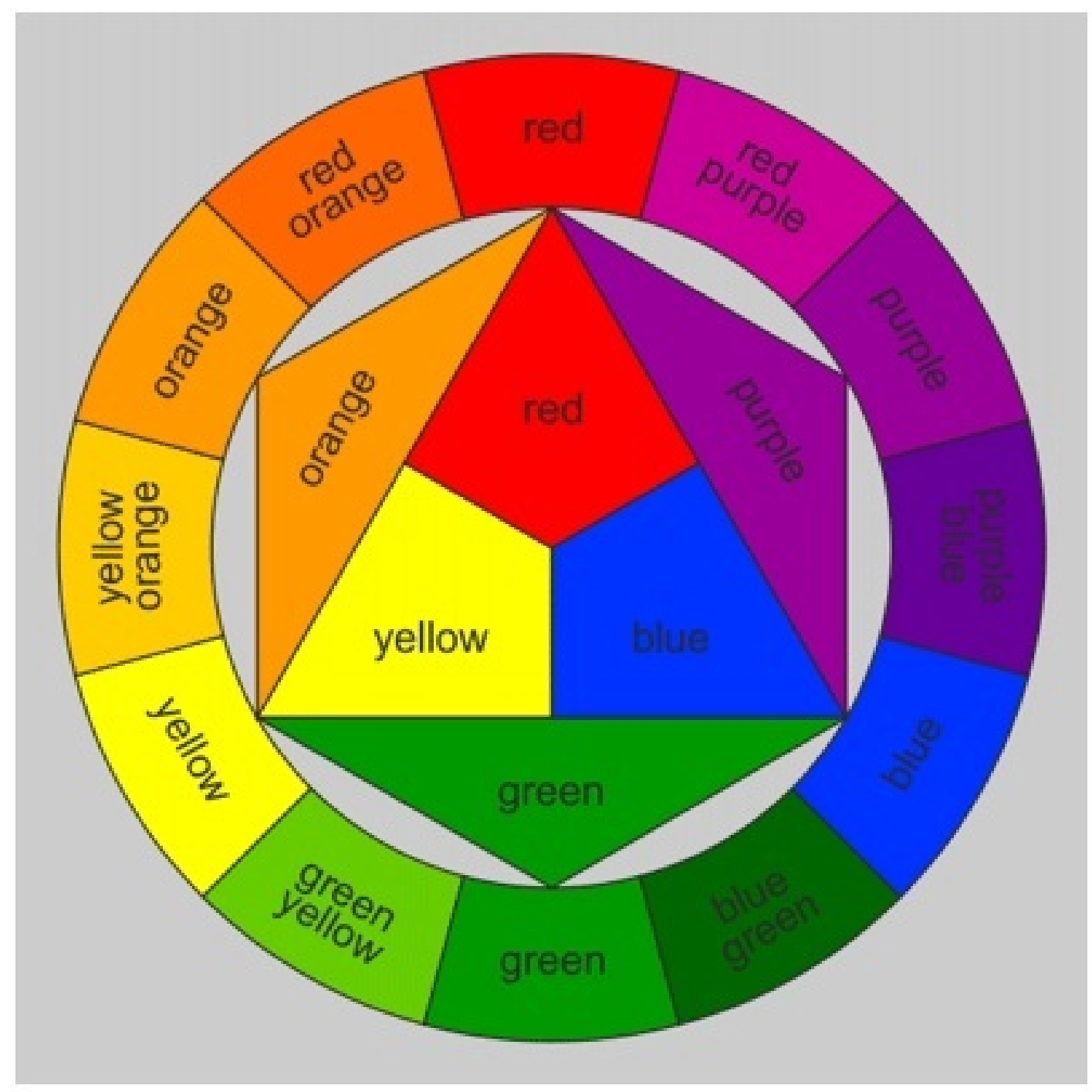

Figure 5. The Colour Wheel (Image with permission from www.artyfactory.com).

The common Western story of colour theory is often demonstrated through the colour wheel. The primary colours are red, yellow, and blue. These colours can mix to create the secondary colours: orange, purple, and green. Complementary colours, such as yellow and purple, are opposite each other on the colour wheel and are understood to be aesthetically pleasing.

The story above reminds us of how stories, texts, images, diagrams, drawings, and paintings are part of how things spread. The colours we see on homes, walls, clothes, carpets, cars, roads, and signs are matched and perfected. Not only are paintings and stories influenced by ways of seeing, and not only do they influence the ways we see, but they also influence the colours all around us. The names we call colours continue to change through colonialism, capitalism, and marketing. 
International Journal of Child, Youth, and Family Studies (2014): 5(4.2) 751-781

So we pay attention to colour, and our use of colour, in our pedagogies. Which paint colours do we offer to children? Which paint colours do we avoid? How do we choose our colours? Next, we continue with the paint to share another story from our art practice, specifically how the colour wheel spreads to our practice. Vanessa tells this story.

\section{Story 14: Spreading the wheel}

As an atelierista, I work with educators to engage with and think deeply about art in early childhood spaces. In my work I draw on knowledge I gained while taking classes at Emily Carr University of Art and Design. Working with educators and children, I often suggest colours to purchase and to work with in the classroom. On one occasion, the educators had a variety of colours in their cupboards. I suggested they provide the children two colours from the following selections: red and yellow, blue and yellow, blue and red, or black and white. These colour selections were suggested so that the children could engage with colour theory and mixing colours. I have taken many courses on colour theory and painting, and in each course we learned about the same colour theory of primary colours, secondary colours, and complementary colours. I remember painting the colour wheel for one art class; we spent two hours to painstakingly paint each square so we would learn the principles of the wheel. A few of my classmates muddied their colours, and I remember the teacher asking them to paint the wheel again for a better mark.

We notice in our use of paint that we are spreading the principles of the colour wheel. These principles are passed on through seemly innocent acts like giving colour suggestions. Vanessa, as an atelierista, is given and assumes authority on art, and the art school she attended exerts power (through grading) by forcing students to learn the wheel. We see how things spread in these everyday circumstances. The colour wheel spreads because students desire good marks; we want to give advice and sound knowledgeable; we follow instructions to please.

We end this section with our final story. Although we use it to close this section, the story is only an opening through which we respond, through our pedagogies, to colonialism and what's covered and spread through it.

\section{Story 15: Transformation}

Sheila and Nicolas stand side by side, with yellow tempera paint covering their hands. A sheet of Plexiglas stands near them on a white drop cloth covered in red and yellow streaks. As Sheila and Nicolas run their yellow hands up and down the Plexiglas, the yellow paint spreads from their hands, covering the Plexiglas. Each time they run their hands farther over the surface of the Plexiglas, the yellow paint spreads out farther and farther.

Sam lifts a brush with a big glob of red paint, his arm out straight, up to the blueand purple-covered Plexiglas. The brush moves around in swirls through the paint. As the brush moves, the blue moves into the purple, the red moves into the blue, and the colours transform. 
International Journal of Child, Youth, and Family Studies (2014): 5(4.2) 751-781

In this story, the colours come together and change one another, often in unequal ways. For example, yellow tends to run out faster because it is easily overpowered by other colours and much more of it is needed to have an effect, whereas blue will take over more easily with only a small amount.

Paying attention to how the paint moves in Story 15, we focus on how it spreads and changes. Reflectively and diffractively, we ask: What makes some stories spread, while others become covered up? What stories do we continue to tell about paint? What stories are silenced? We wonder about the ethics of our pedagogies and the politics of what and who lives and dies through them. What do we privilege? What do we maintain under cover? Which colours never make it to the easel or the paper or the children's bodies?

\section{Concluding Intentions}

The art pedagogies we use in early childhood classrooms are garnered from violent imperial settler colonial histories, yet they are often taken as innocent. Throughout our stories we have seen how categories of "the Native”, "the European”, and "the hybrid" are produced through art. We have presented stories of colonialism and paint to foreground colonialism's and paint's complexity - all the different ways (e.g., smooth, gritty, spreading, layers) that colonialism appears through paint produce depth, texture, and movement. Understanding stories as having properties and doing things, we attend to how we might respond to these stories. For example, in the stories we told when we attended to how stories sometimes add to, cover up, and blur one another, we call attention, through our storytelling, to the ethics of how we layer, what we cover, and why we blur. Our methodology of storytelling with paint is an attempt to bring forward the politics of colonialism - to make these politics visible through the qualities of paint and what paint does.

In our art pedagogies we are attempting to seriously engage in contested sites of colonial struggle, and this paper has been a way of doing this. Again, our attempts are, of course, always partial and imperfect (Tuck \& Yang, 2012). We hope that readers do not see our pedagogies or our actions as linear and rational: There is nothing linear about what we do. These events are emergent. They happen, they flow, they layer onto each other. Sometimes they bring specific provocations to stretch children's thinking and our own. At other times, interesting occurrences take over and ask that we do something with them. Yet we work with intentionality to interrupt colonization. Like paint, and like the stories we have told in this paper, our practices at times become sticky, while at other times they smooth out, become gritty, and change in non-logical ways.

Thinking with paint has allowed us to trouble our early childhood art pedagogies and open them up to become more worldly as we showed how we are always implicated in colonialism. 
International Journal of Child, Youth, and Family Studies (2014): 5(4.2) 751-781

\section{References}

Ahmed, S. (2007). A phenomenology of whiteness. Feminist Theory, 8(2), 149-168. doi:10.1177/1464700107078139

Alfred, G. T. (2010). Our art is our life: The power of Marianne Nicolson's work. Retrieved from http://moa.ubc.ca/borderzones/features_nicolson.html

Alfred, G. T., \& Corntassel, J. (2005). Being indigenous: Resurgence against indigenous colonialism. Politics of Identity, 40(4), 497-614. doi: 10.1111/j.1477-7053.2005.00166.x

Altamirano-Jiménez, I. (2008). The colonization of indigenous diversity. In L. Simpson (Ed.), Lighting the eighth fire (pp. 175-185). Winnipeg, MB: Arbeiter Ring.

Armstrong Hall, E. (2006). Crayola crayon. In D. Hall \& S. Hall (Eds.), American icons (pp. 180-185). Westport, CT: Greenwood Press.

Arnold, D. (2004). Art history: A very short introduction. Padstow, UK: TJ International. http://dx.doi.org/10.1093/actrade/9780192801814.001.0001

Arvin, M., Tuck, E., \& Morrill, A. (2013). Decolonizing feminism: Challenging connections between settler colonialism and heteropatriarchy. Feminist Formations, 25(1), 8-34. http://dx.doi.org/10.1353/ff.2013.0006

Ashley, M. (2009). Education for freedom: The goal of Steiner/Waldorf schools. In P. Woods \& G. Woods (Eds.), Alternative education for the 21st century: Philosophies, approaches, visions (pp. 209-225). New York: Palgrave Macmillan.

Avramov, I. (2005). Viscosity in disordered media. Journal of Non-Crystalline Solids, 351(40), 3163-3173. doi: 10.1016/j.jnoncrysol.2005.08.021

Battiste, M. (2004, May 29). Animating sites of postcolonial education: Indigenous knowledge and the humanities. Canadian Society for the Study of Education plenary address. Retrieved from http://www.usask.ca.ezproxy.library.uvic.ca/education/people/battistem/pdf/csse_battiste. pdf

Becker, C. (1996). Zones of contention: Essays on art, institutions, gender, and anxiety. Albany, NY: SUNY Press.

Belmore, R., \& Spang, B. (2003). A way of making (art exhibit). Retrieved from http://ccca.concordia.ca/performance_artists/b/belmore/belm_perf1/index.html

Berman, T. (2012). Introduction. In T. Berman (Ed.), Indigenous arts and the politics of possession. Santa Fe, NM: School for Advanced Research Press.

Bleicher, S. (2012). Contemporary color: Theory and use (2nd ed.). Stamford, CT: Delmar Cengage Learning. 
International Journal of Child, Youth, and Family Studies (2014): 5(4.2) 751-781

Boas, F. (1921). Ethnology of the Kwakiutl, (Vol. 35, part 1). Washington, DC: Government Printing Office.

Braun, B. (2002). Colonialism's afterlife: Vision and visuality on the Northwest coast. Cultural Geographies, 9(2), 202-247. http://dx.doi.org/10.1191/1474474002eu243oa

Burman, E. (2008). Deconstructing developmental psychology (2nd ed.). New York: Routledge.

Byrd, J. (2011). Transit of empire: Indigenous critiques of colonialism. Minneapolis, MN: University of Minnesota Press.

Carr, E. (1966). Hundred and thousands: The journal of Emily Carr. Vancouver, BC: Douglas \& McIntyre.

Cavallini, I., Filippini, T., Vecchi V., \& Trancossi L. (2011). Wonders of learning. Reggio Emilia, Italy: Reggio Children.

Ceppi G., \& Zini, M. (1998). Children, spaces, relations-Metaproject for an environment for young children. Cavriago, Italy: Grafiche Maffei.

DeVan, K. (2008, Fall). Crayola colors children's memories in 64 shades and more. Retrieved from http://pabook.libraries.psu.edu/palitmap/Crayola.html

Drogin, D., \& Zucker, S. (Speakers). (n.d.). Tempera paint [Video file]. Khan Academy. Retrieved from http://www.khanacademy.org/humanities/art-history/introduction-to-arthistory/v/tempera-paint

Duncum, P. (1982). The origins of self-expression: A case of self-deception. Art Education, 35(5), 32-35. http://dx.doi.org/10.2307/3192633

Eaton, D. F., \& Urbanek, S. (1995). Paul Kane’s great north-west. Vancouver, BC: UBC Press.

Fletcher, V. D. (n.d.). Artist's statement. Retrieved from http://cargocollective.com/dionfletcher

Fuga, A. (2006). Artists’ techniques and materials. Los Angeles: Getty Publications.

Giudici, C., \& Vecchi, V. (1994). Children, art, artists. Reggio Emilia, Italy: Reggio Children.

Hall, S. (Lecturer), \& Jhally, S. (Producer/Director). (2009, November 2). Race, the floating signifier [Video file]. Northampton, MA: Media Education Foundation. Retrieved from http://www.youtube.com/watch?v=rYGeqryELXk

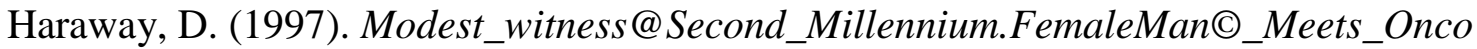
Mouse ${ }^{\mathrm{TM}}$ : Feminism and technoscience. New York: Routledge.

Haraway, D. (2008). When species meet. Minneapolis, MN: University of Minnesota Press. 
International Journal of Child, Youth, and Family Studies (2014): 5(4.2) 751-781

Hilden, P., \& Lee, L. (2010). Indigenous feminism: The project. In C. Suzack, S. Huhndorf, J. Perreault, \& J. Barman (Eds.), Indigenous women and feminism: Politics, activism, culture (pp. 56-77). Vancouver, BC: UBC Press.

Instone, L. (2009). Encountering native grasslands: Matters of concern in an urban park. Australian Humanities Review, 49, 91-117.

Joseph, R. (2005). Listening to our ancestors: The art of native life along the north Pacific coast. Washington, DC: National Museum of the American Indian, Smithsonian Institute, in association with National Geographic.

Kellogg, R. (1969). Analyzing children’s art. Palo Alto, CA: National Press Books. (Original work published 1898)

Kind, S. (2010). Art encounters: Movements in the visual arts and early childhood education. In V. Pacini-Ketchabaw (Ed.), Flows, rhythms, and intensities of early childhood education curriculum (pp. 113-131). New York: Peter Lang.

Kirsh, A., \& Levenson, R. (2000). Seeing through painting: Physical examination in art historical studies. New Haven, CT: Yale University Press.

Kissick, J. (1993). Art, context and criticism. Madison, WI: Brown \& Benchmark.

Landscape Oil Painting Gallery. (n.d.). Albert Bierstadt. Retrieved from http://www.landscapeoilpaintingsgallery.com/portfolio-item/albert-bierstadt/

Lenz Taguchi, H. (2012). A diffractive and Deleuzian approach to analysing interview data. Feminist Theory, 13(3), 265-281. http://dx.doi.org/10.1177/1464700112456001

Lowenfeld, V., \& Brittain, W. L. (1975). Creative and mental growth (6th ed.). New York: Macmillan.

MacLure, M. (2011). Qualitative inquiry: Where are the ruins? Qualitative Inquiry, 17(10), 9971005. http://dx.doi.org/10.1177/1077800411423198

Matthews, J. (2003). Drawing and painting: Children and visual representation (2nd ed.). Thousand Oaks, CA: Sage.

McChesney, L. (2012). (Art)writing: A new cultural frame for Native American art. In T. Berman (Ed.), Indigenous arts and the politics of possession (pp. 2-31). Santa Fe, NM: School for Advanced Research Press.

McEvilley, T. (1998). What is at stake in the culture wars? In R. Roth \& S. Kind Roth (Eds.), Beauty is nowhere: Ethical issues in art and design (pp. 17-36). Amsterdam, The Netherlands: G + B Arts International Imprint.

McFadden, K. (n.d.). Contemporary native art in a primitive art world. Retrieved from http://www.uwo.ca/visarts/research/2007-08/WUJAVC/10mcfadden.html 
International Journal of Child, Youth, and Family Studies (2014): 5(4.2) 751-781

McLennan, B., \& Duffek, K. (2000). The transforming image: Painted arts of northwest coast First Nations. Vancouver, BC: UBC Press.

Miller, J., Moffatt, E., \& Sirois, J. (1990). Canadian Conservation Institute native materials project report. Royal Ontario Museum. Ottawa, ON: Canadian Conservation Institute.

Mol, A. (2002). The body multiple: Ontology in medical practice. Durham, NC: Duke University Press.

Morgensen, S. (2011). Spaces between us: Queer settler colonialism and indigenous decolonization. Minneapolis, MN: University of Minnesota Press.

Pacini-Ketchabaw, V., Kind, S., \& Kocher, L. (2012, April 17). Encounters with materials in early childhood education. Paper presented at the annual general meeting of the American Educational Research Association, Vancouver, BC.

Razack, S. (1998). Looking white people in the eye: Gender, race, and culture in courtrooms and classrooms. Toronto: University of Toronto Press.

Reeves \& Poole Group Inc. (n.d.). Funstuff. Retrieved from: http://www.rp-funstuff.com/

Rivet, R. (n.d.). Artist’s statement. Retrieved from: http://www.rickrivet.ca/statement.php

Roark, E. (2003). Artists of colonial America. Westport, CT: Greenwood Press.

Shearar, C. (1969). Understanding northwest coast art: A guide to crests, beings, and symbols. Seattle, WA: University of Washington Press.

Shiner, L. (2003). The invention of art: A cultural history. Chicago: University of Chicago Press.

Simpson, L. (2011). Dancing on our turtle's back: Stories of Nishnaabeg re-creation, resurgence, and a new emergence. Winnipeg, MB: Arbeiter Ring.

Smith, A. (2011). Queer theory and native studies: The heteronormativity of settler colonialism. In Q. Driskill, C. Finley, B. Gilley, \& S. Morgensen (Eds.), Queer indigenous studies: Critical interventions in theory, politics, and literature (pp. 43-65). Tucson: University of Arizona Press.

Smith, L. (2012). Decolonizing methodologies: Research and Indigenous peoples (2nd ed.). London: Zed Books.

Smyly, J., \& Smyly, C. (1973). Those born at Koona. Saanichton, BC: Hancock House.

Steele, B. (n.d.). The highest point, still contained. Retrieved from http://www.steeleartist.com/statement.html

Steiner, R. (1922). Spiritual ground of education: The organization of the Waldorf School. Retrieved from: http://wn.rsarchive.org/Education/19220823p01.html 
International Journal of Child, Youth, and Family Studies (2014): 5(4.2) 751-781

Steiner, R. (1937). On the plastically formative arts, music, and poetry (H. Collison, Trans.). Rudolph Steiner Archive. Retrieved from: http://wn.rsarchive.org/Education/GA294/English/RSPC1937/19190823n01.html

Sullivan, G. (2006). Research acts in research practice. Studies in Art Education: A Journal of Issues and Research, 48(1), 19-35.

Tarr, P. (1995). Preschool children's socialization through art experiences. In C. Thompson (Ed.), The visual arts and early childhood learning (pp. 23-27). Reston, VA: National Art Education Association.

Taylor, A. (2013). Reconfiguring the natures and cultures of childhood. London: Taylor \& Francis.

Temkin, A. (2008). Color chart: Reinventing color. New York: Museum of Modern Art.

Thobani, S. (2007). Exalted subjects: Studies in the making of race and nation in Canada. Toronto: University of Toronto Press.

Tuck, E., \& Yang, K. W. (2012). Decolonization is not a metaphor. Decolonization: Indigeneity, Education \& Society, 1(1), 1-40.

Turner, D. (1992). When the rains came and other legends of the Salish people. Victoria, BC: Orca.

Valluzzi, R. (2011). Viscosity: Why does it matter? The Nerdly Painter. Retrieved from http://nerdlypainter.blogspot.ca/2011/01/viscosity-why-does-it-matter.html

Victor, W. (2006). Searching for the bone needle: A journey in coming to understand Aboriginal justice. Justice as Healing: A Newsletter on Aboriginal Concepts of Justice, 11(1). Retrieved from http://www.usask.ca/nativelaw/publications/jah/2006/Seach_bone_needle.pdf

Wyatt, G. R. (1999). Mythic beings: Spirit art of the northwest coast. Vancouver, BC: Douglas \& McIntyre. 